\title{
Isolasi, Identifikasi dan Aktivitas Antibakteri Bakteri Endofit Daun Pegagan \\ (Centella asiatica L.) terhadap Escherichia coli
}

\author{
Adityawarman $^{1} ;$ Mahyarudin $^{2} ;$ Effiana $^{2}$ \\ ${ }^{1}$ Program Studi Kedokteran, FK UNTAN \\ ${ }^{2}$ Departemen Mikrobiologi, Program Studi Kedokteran, FK UNTAN
}

\begin{abstract}
Abstrak
Latar Belakang. Di Indonesia diare masih merupakan masalah kesehatan masyarakat. Tanaman pegagan telah digunakan untuk pengobatan diare. Bakteri endofit adalah bakteri yang hidup di dalam jaringan tanaman inang. Beberapa jenis bakteri endofit mampu menghasilkan senyawa aktif yang bersifat antibiotik. Metode. Penelitian ini merupakan penelitian deskriptif-eksploratif. Isolasi bakteri endofit dari daun pegagan (C.asiatica L.) menggunakan metode tanam langsung, potensi antibakteri diuji dengan metode difusi cakram. Identifikasi bakteri endofit dilakukan dengan pengamatan morfologi koloni, morfologi sel dan uji biokimia. Hasil. Sebanyak 4 dari 42 isolat memiliki potensi sebagai antibakteri terhadap pertumbuhan bakteri Escherichia coli. Isolat 16 memiliki kemampuan tertinggi yaitu dengan zona hambat $6,5 \mathrm{~mm}$. isolat 16 memiliki kemiripan dangan genus Pseudomonas. Kesimpulan. Sebanyak 4 isolat bakteri endofit yang mempunyai potensi antibakteri terhadap Escherichia coli
\end{abstract}

Kata Kunci: Centella asiatica L., Bakteri endofit, Escherichia coli, zona hambat.

Background. Diarrhea in indonesia has become one of main health social problem. Centella has been used for the treatment of diarrhea. Endophytic bacteria are bacteria that live in the tissues of host plants. Several types of endophytic bacteria are known to produce active compounds that are antibiotics. Method. This research was a descriptive-explorative research. Isolation of endophyte bacteria from centella leaf (C.asiatica L.) was done by direct cropping method, a potency of antibacterial tested by disc diffusion method. Identification of endophytic bacteria was done by observation of colony morphology, cell morphology and biochemical test. Result. Total of 4 isolates from 42 isolates had antibacterial activity againts E.coli. the isolate 16 had highest antibacterial activity againts E. Coli with $6.5 \mathrm{~mm}$ inhibition zone, isolates 16 had similarities with the genus Pseudomonas. Conclusion. Four isolates of endophytic bacteria have antibacterial potency againts E. coli

Keywords: Centella asiatica L., Endophyte bacteria, Escherichia coli, inhibition zone. 


\section{PENDAHULUAN}

Diare adalah buang air besar dengan feses yang berbentuk cair atau setengah cair, kandungan air pada feses lebih banyak dari biasanya yaitu lebih dari 200 gram atau 200 ml $/ 24 \mathrm{jam}{ }^{1} \quad \mathrm{Di}$ Indonesia diare masih merupakan masalah kesehatan masyarakat. Menurut data dari Kemenkes RI pada tahun 2015 telah terjadi kejadian luar biasa (KLB) di 11 provinsi dengan kasus sebanyak 1.213 penderita dengan angka kematian diare sebanyak 2,47\%. ${ }^{2}$ Provinsi Kalimantan Barat khususnya kota Pontianak pada tahun 2015, dilaporkan bahwa angka kejadian diare sebanyak 13.532 kasus dan masih termasuk 10 besar penyakit yang dilayani oleh puskesmas. ${ }^{3}$ Diare dapat disebabkan oleh bakteri, virus, parasit dan lain-lain. Di negara berkembang, prevalensi diare akut akibat bakteri dan parasit lebih tinggi dibandingkan akibat virus. ${ }^{4}$ Satu satu penyebab diare adalah Escherichia coli. ${ }^{1}$

Escherichia coli merupakan bakteri normal yang ada di usus. Bakteri ini merupakan bakteri gram negatif yang berbentuk batang. Escherichia coli termasuk famili Enterobacteriaceae yang memiliki karakteristik tumbuh secara anaerob maupun fakultatif anaerob. ${ }^{5}$ Diare akut yang terjadi, umumnya karena tidak cukupnya ketersediaan air bersih dan higiene yang buruk. ${ }^{6}$ Pengobatan untuk diare akut adalah dengan rehidrasi cairan, diet, obat diare dan antibiotik. ${ }^{7}$ Antibiotik merupakan obat yang paling banyak digunakan pada infeksi yang disebabkan oleh bakteri. Intensitas penggunaan antibiotik yang relatif tinggi menimbulkan berbagai permasalahan dan merupakan ancaman global bagi kesehatan terutama resistensi bakteri terhadap antibiotik. ${ }^{8}$ Untuk mengatasi infeksi mikroorganisme yang telah resisten terhadap antibiotik dapat menggunakan tanaman obat sebagai pengobatan alternatif. ${ }^{9}$ Satu diantara tanaman obat tradisional yang memiliki efek pengobatan yaitu tanaman pegagan.

$$
\text { Tanaman pegagan merupakan }
$$
tanaman liar yang banyak tumbuh di 
perkebunan, ladang, tepi jalan, pematangan sawah ataupun di ladang. ${ }^{10}$ Tanaman pegagan telah dilaporkan digunakan untuk pengobatan ulkus lambung, asma, epilepsi, hepatitis, sifilis dan diare. ${ }^{11}$

Tanaman herbal ini sering digunakan oleh masyarakat baik dalam bentuk segar, kering maupun dalam bentuk ramuan (jamu). Tanaman ini mengandung berbagai bahan aktif seperti triterpenoid, saponin dan kandungan kimia dari pegagan terbagi menjadi beberapa golongan, yaitu asam amino, flavonoid, terpenoid dan minyak atsiri. ${ }^{12}$ Flavonoid yang terkandung pada tanaman pegagan memiliki bioaktivitas sebagai antikanker, antivirus, antiperadangan dan antialergi. ${ }^{13}$ Fungsi lain dari pegagan antara lain sebagai obat penenang, obat penghilang sakit, antidepressive dan antimikroba. ${ }^{14}$ Hasil penelitian telah melaporkan bahwa ekstrak metanol dari tanaman pegagan memiliki aktivitas antibakteri terhadap bakteri Staphylococcus aureus, Shigella boydii, Pseudomonas aeruginosa dan Escherichia coli. ${ }^{15}$ Pada tanaman terdapat mikroorganisme yang dapat memproduksi metabolit sekunder dengan kemampuan sebagai antibakteri yang disebut bakteri endofit. $^{16}$

Bakteri endofit adalah bakteri yang hidup di dalam jaringan tanaman inang tanpa menyebabkan gejala-gejala penyakit. ${ }^{17}$ Bakteri endofit hidup di dalam jaringan vaskular tumbuhan tanpa menyebabkan efek negatif. Hubungan simbiosis mutualisme antara bakteri dan tumbuhan memungkinkan bakteri menghasilkan senyawa bioaktif yang sama seperti terkandung di dalam tumbuhan inangnya. ${ }^{18}$ Mikroorganisme endofit dapat ditemukan pada berbagai jaringan diantaranya biji, ovula buah, batang, akar, umbi akar dan daun. ${ }^{19,20}$ Beberapa jenis bakteri endofit diketahui mampu menghasilkan senyawa aktif yang bersifat antibiotik. $^{21}$

Beberapa bakteri endofit mampu menghasilkan produk potensial yaitu 
Streptomyces griseus dari tanaman

Kandelia candel menghasilkan asam p-aminoacetophenonic

sebagai

antimikroba. ${ }^{22}$ Streptomyces NRRL 30562

dari tanaman Kennedia nigriscans

menghasilkan munumbicin (antibiotik) dan

munumbicin D (antimalaria). Serratia

marcescens dari tanaman Rhyncholacis

penicillata menghasilkan oocydin A

sebagai antifungal. ${ }^{23}$ Bakteri Endofit yang

diisolasi dari suatu tanaman dapat

menghasilkan metabolit sekunder yang

sama dengan tanaman aslinya. $^{24}$

Keuntungan lain yang diperoleh dari

pengembangan bakteri endofit adalah

dapat menjaga kelestarian tanaman obat,

terutama jenis tanaman obat yang langka

agar tidak digunakan secara terus menerus

sehingga tidak menurunkan jumlah

populasi. $^{25}$

Penelitian mengenai isolasi, identifikasi dan aktivitas bakteri endofit dari daun pegagan terhadap bakteri E. coli hingga saat ini belum pernah dilakukan. Berdasarkan latar belakang tersebut, maka peneliti bertujuan untuk melakukan penelitian mengenai isolasi, identifikasi dan aktivitas bakteri endofit dari daun pegagan (C. asiatica L.) terhadap E. Coli. Penelitian ini bertujuan untuk mengetahui efek antibakteri bakteri endofit dari daun pegagan $(C$. asiatica $\mathrm{L}$.) terhadap bakteri E. coli.

\section{METODE}

\section{Alat Penelitian}

Alat yang digunakan dalam penelitian ini adalah cawan petri, tabung reaksi, rak tabung reaksi, batang pengaduk pipet volume, mikropipet, plastik wrapping, erlenmeyer, penangas, ose, bunsen, vortex mixer, gelas objek, penjepit gelas objek, preparat, spidol, jangka sorong, pinset, korek api, Laminar Air Flow Cabinet, autoklaf, inkubator, neraca analitik, mikroskop cahaya, gelas beaker, lemari pendingin, gelas ukur, gunting bedah steril, pipet tetes dan hotplate. 


\section{Bahan Penelitian}

Bahan-bahan yang digunakan dalam penelitian ini adalah daun pegagan (Centela asiatica L.), biakan murni bakteri Escherichia coli, kantong plastik, kertas cakram, kertas timbang, plastik wrapping, tube mikropipet, spiritus, handscoon, Media Nutrient Agar, Media Nutrient Broth, Media Mueller Hinton Agar, aquades steril, alkohol $70 \%$, larutan standar Mc Farland, minyak emersi, kristal violet, alkohol 96\%, safranin, nistatin $30 \%$, siprofloksasin, larutan NaOCL $1 \%$, reagen tetrametil paraphenildiamin, media MIO (Motility Indole Ornitin), media SIM (sulfida indol motility), $\mathrm{H}_{2} \mathrm{O}_{2} 30 \%$, media glukosa, media sukrosa, media laktosa, media maltosa, media sorbitol, media manitol, media inositol, media urea, media O-F 0,5-1\% karbohidrat, media Simmons Citrat Agar, media TSIA, NaCL steril larutan $\mathrm{H}_{2} \mathrm{SO}_{4} \quad 1 \%$ dan larutan (BaCl2.2H2O) 1,175\%.

\section{Pengambilan Daun Pegagan}

Sampel daun yang sehat diperoleh di jalan Khatulistiwa Kecamatan Pontianak timur Kota Pontianak. Sampel yang terkumpul dibawa ke Laboratorium Mikroskopik di Fakultas Kedokteran Universitas Tanjungpura kota pontianak.

\section{Determinasi}

Determinasi tanaman pegagan dilakukan di Laboratorium Biologi fakultas Matematika dan Ilmu Pengetahuan Alam (MIPA) Universitas Tanjungpura kota Pontianak provinsi Kalimantan Barat.

\section{Sterilisasi Permukaan Daun}

Daun pegagan dicuci menggunakan air, kemudian permukaan daun disterilisasi secara bertahap dengan cara merendam di alkohol $70 \%$ selama 1 menit, kemudian direndam di dalam larutan $1 \%$ sodium hypochlorite $(\mathrm{NaOCl})$ selama 5 menit, diikuti dengan merendam di alkohol $70 \%$ selama 1 menit. Pada tahap akhir sterilisasi daun, sampel dibilas 3 kali dengan aquades steril. 


\section{Konfirmasi Keberhasilan}

Aquades steril pada bilasan terakhir

diambil sebanyak $100 \mu \mathrm{L}$ dan diisolasikan

pada media NA dengan dengan menggunakan metode cawan sebar. Jika ditemukan pertumbuhan bakteri pada media, maka bakteri hasil isolasi bukanlah bakteri endofit. Sedangkan pada media NA yang tidak ditumbuhi bakteri, maka bakteri yang tumbuh hasil isolasi awal tersebut adalah bakteri endofit.

Isolasi, Pemurnian dan Subkultur

\section{Bakteri Endofit}

Daun yang telah disterilisasi kemudian dikeringkan di atas kertas saring steril. Daun dipotong dengan menggunakan pisau bedah steril di dalam Laminar Air Flow Cabinet (LAFC) dan daun dipotong-potong menjadi beberapa bagian dengan menggunakan prosedur aseptik. Bagian dari daun tersebut diinokulasikan pada media nutrien agar (NA) kemudian ditambahkan dengan agen antijamur yaitu nistatin pada konsentrasi $30 \mathrm{ug} / \mathrm{mL}$. Setiap cawan petri berisi tiga atau empat potongan daun. Cawan petri yang berisi sampel daun disegel menggunakan pita paraffin dan diinkubasi pada $37^{\circ} \mathrm{C}$ selama $24-48$ jam.

Bakteri yang tumbuh pada media NA setelah 24-48 jam disubkultur pada media agar nutrien dengan metode cawan gores (streak plate method). Semua isolat bakteri endofit yang tumbuh dilakukan pemurnian dan peremajaan isolat berdasarkan morfologi koloni. Setiap isolat bakteri endofit dibuat dua pada media agar miring, masing-masing dipergunakan sebagai working culture dan stock culture.

\section{Peremajaan dan Konfirmasi Bakteri Uji}

Satu koloni bakteri E. Coli diinokulasikan pada media NA dengan metode cawan gores (streak plate method), setelah itu diinkubasi dalam inkubator pada suhu $37^{\circ} \mathrm{C}$ selama 24 jam. Peremajaan ini dilakukan karena dalam pengujian aktivitas antibakteri diperlukan koloni bakteri segar yang berusia 24 jam. ${ }^{71}$ 


\section{Pembuatan Larutan Mc Farland}

Pembuatan larutan Mc Farland

dilakukan dengan cara mencampurkan

$0,05 \mathrm{ml}$ barium klorida $1,175 \%$

$(\mathrm{BaCl} 2.2 \mathrm{H} 2 \mathrm{O})$ dan $9,95 \mathrm{ml}$ asam sulfat $1 \%$

(H2SO4).

\section{Pembuatan Suspensi Bakteri Uji}

Pembuatan suspensi bakteri dilakukan secara aseptis dengan cara koloni bakteri uji pada media peremajaan yang berumur 24 jam diambil dengan menggunakan jarum ose dan disuspensikan ke dalam tabung berisi 5 mL larutan $\mathrm{NaCl}$ steril $0,9 \%$. Kekeruhan yang diperoleh kemudian disetarakan dengan standar Mc farland 0,5\% yaitu setara dengan jumlah pertumbuhan $1,5 \times 10^{8} \mathrm{CFU} / \mathrm{mL}$.

\section{Kontrol Positif dan Negatif}

Kontrol positif yang digunakan dalam penelitian ini adalah siprofloksasin. Kontrol negatif yang digunakan dalam penelitian ini adalah aquades

\section{Uji Sensitivitas Antibiotik}

Suspensi bakteri uji diambil $200 \mu \mathrm{L}$ dan diratakan pada permukaan media Mueller Hinton Agar (MHA). Permukaan media diberi kertas cakram 4 buah dan kertas cakram tersebut ditetesi suspesi isolat bakteri endofit kemudian diinkubasi dalam inkubator dengan suhu $37^{\circ} \mathrm{C}$ selama 24 jam. Zona bening pada daerah sekitar antibiotik menunjukkan adanya sensitivitas terhadap bakteri uji.

\section{Produksi Metabolit Antibakteri dari}

\section{Bakteri Endofit}

Produksi metabolit antibakteri dilakukan dengan metode isolat bakteri endofit yang tumbuh pada medium NA diinokulasikan pada media NB yang bertujuan untuk memproduksi metabolit antibakteri dari bakteri endofit. Isolat bakteri endofit diambil menggunakan jarum ose dan diinokulasikan kedalam tabung tabung reaksi $10 \mathrm{~mL}$ yang berisi media cair NB. Tabung reaksi kemudian diinkubasi pada suhu $37^{\circ} \mathrm{C}$ selama 2-3 hari dalam kondisi stasioner kemudian 
homogenisasi menggunakan vortex. dikarakterisasi dan diidentifikasi yang

Kemudian isolat diuji dengan metode

difusi cakram untuk uji terhadap bakteri

patogen.

\section{Skrining Bakteri Endofit Potensial}

Biakan murni bakteri endofit yang diperoleh diuji potensi antibakterinya terhadap E. coli dengan metode Paper Disc Agar Diffusion Technique. Suspensi bakteri uji yang telah diukur kepadatannya kemudian disebar di permukaan media MHA dengan metode swab. Sebanyak $20 \mu \mathrm{L}$ suspensi bakteri endofit hasil homogenisasi diserapkan pada cakram steril berdiamter $6 \mathrm{~mm}$. Kemudian dilakukan inkubasi selama 24 jam pada suhu $37^{\circ} \mathrm{C}$ dan diamati ada atau tidaknya zona bening yang terbentuk.

\section{Pengukuran Zona Hambat}

Zona hambat yang terbentuk di sekitar cakram kertas saring diukur menggunakan jangka sorong.

Bakteri murni yang memiliki efek aktivitas antibakteri tertinggi kemudian dilakukan secara biokimia dengan mengacu pada Bergey's Manual of Determinative Bacteriology. karakterisasi yang dilakukan meliputi pengamatan morfologi koloni, morfologi sel dan biokimia bakteri

\section{HASIL}

Determinasi Tumbuhan

Hasil Determinasi tumbuhan Pegagan dilakukan di Laboratorium Biologi Fakultas Matematika dan Ilmu Pengetahuan Alam (FMIPA) Universitas Tanjungpura Kota Pontianak. Hasil determinasi menunjukkan bahwa tumbuhan yang digunakan adalah tumbuhan dari famili Apiaceae dengan nama spesies Centella asiatica L. genus Centella.

\section{Sterilisasi}

Hasil sterilisasi permukaan daun pegagan yaitu terdapat adanya pertumbuhan bakteri di sekitar daun pada petri yang berisi daun dan tidak adanya 
pertumbuhan bakteri pada cawan petri konfirmasi keberhasilan sterilisasi daun.

\section{Isolasi Bakteri Endofit}

Telah diperoleh hasil pemurnian isolat bakteri endofit daun pegagan yang berjumlah 42 isolat murni.

\section{Hasil Konfirmasi Bakteri Uji}

Hasil konfirmasi bakteri uji pada media NA menunjukkan koloni berwarna putih kekuningan, sirkular dan tepian utuh. Hasil konfirmasi bakteri uji dilanjutkan dengan metode pewarnaan gram. bakteri tesebut merupakan gram negatif, berwarna merah dan berbentuk batang. Pada media EMBA (Eosin Methylene Blue Agar) didapatkan pertumbuhan koloni berbentuk bulat dan berwarna hijau metalik.

\section{Hasil Uji Aktivitas}

. Hasil pengujian aktivitas bakteri endofit daun pegagan terhadap E. coli didapatkan sebanyak 4 isolat bakteri endofit dari 42 isolat memiliki aktivitas terhadap E. coli. Aktivitas isolat bakteri endofit berkisar antara $2 \mathrm{~mm}-6,5 \mathrm{~mm}$ (aktivitas lemah-sedang) sedangkan kontrol positif sensitif terhadap bakteri $E$. coli.

\section{Hasil Identifikasi Isolat}

Isolat bakteri endofit yang memiliki zona hambat terbesar yaitu isolat nomor 16. Isolat bakteri endofit paling potensial yang berhasil di isolasi dari daun pegagan memiliki karakter morfologi sel berbentuk bulat dan termasuk kedalam golongan bakteri gram negatif.

Uji biokimia bakteri endofit dilakukan di ULK (Unit Laboratorium Kesehatan) Dinas Kesehatan Provinsi. Hasil uji biokimia isolat bakteri endofit yang memiliki kemampuan menghambat pertumbuhan E. coli yang paling potensial menunjukkan bahwa isolat bakteri endofit nomor 16 merupakan bakteri fakultatif anaerob, bakteri tidak motil, fermentasi karbohidrat negatif, indol negatif, $\mathrm{H}_{2} \mathrm{~S}$ negatif, urease negatif, simon sitrat negatif, katalase positif dan fermentatif glukosa OF 
Hasil identifikasi isolat bakteri endofit mengacu pada Bergey's Manual of Determinative Bacteriology. Bakteri endofit memiliki kemiripan karakterisitik morfologi sel dan biokimia yang sama dengan genus Pseudomonas

\section{PEMBAHASAN}

Bakteri endofit adalah bakteri yang hidup dalam jaringan tanaman yang dapat diisolasi melalui sterilisasi permukaan jaringan. ${ }^{26}$ Jumlah bakteri endofit di dalam tanaman tidak dapat ditentukan secara pasti, namun bakteri ini dapat dideteksi dengan mengisolasi pada media agar. ${ }^{27}$ Penggunaan media NA lebih cocok untuk isolasi bakteri endofit dan ditambahkan nistatin sebagai antifungi. ${ }^{28,29}$ Bakteri endofit yang tumbuh pada media NA yang secara makroskopis berbeda dianggap merupakan isolat yang berbeda, namun jika koloni bakteri endofit yang tumbuh di media pertumbuhan yang secara makroskopis sama dianggap isolat yang sama. Bakteri endofit yang berbeda kemudian dilakukan pemurnian. Dari hasil setiap bakteri yang dimurnikan didapatkan 42 isolat bakteri endofit. Penelitian sebelumnya yang dilakukan oleh Sari didapatkan 3 isolat aktinomiset endofit dari daun pegagan sebagai antihipertensi. ${ }^{30}$ Sebanyak 4 dari 42 isolat Isolat bakteri endofit memberikan efek zona hambat/bening terhadap bakteri Escherichia coli. Berdasarkan tabel 4.2 terdapat 4 isolat akitf yang mampu menghambat pertumbuhan bakteri uji. Masing masing isolat memiliki zona hambat, isolat 16 memiliki zona hambat sebesar $6,5 \mathrm{~mm}$, isolat 36 memiliki zona hambat sebsear $4,5 \mathrm{~mm}$, isolat 26 dan 30 memeiliki zona hambat sebesar $2 \mathrm{~mm}$. hal ini menunjukkan bahwa bakteri endofit dari daun pegagan mampu menghasilkan metabolit sekunder sebagai antibakteri dikarenakan bakteri endofit tersebut memiliki metabolit sekunder yang sama dengan tanaman inangnya. ${ }^{31}$ Terdapat 38 isolat yang tidak menghasilkan zona 
hambat pada isolat bakteri endofit nomor $1,2,3,4,5,6,7,8,9,10,11,12,13,14$, $15,17,18,20,21,22,23,24,25,27,28$, $29,31,32,33,34,35,37,38,39,40,41$ dan 42. Sedangkan kontrol positif pada penelitian memiliki zona hambat sebesar $39 \mathrm{~mm}$. Terbentuknya zona hambat juga dipengaruhi oleh faktor lingkungan dan bakteri uji yang berlebihan. ${ }^{32}$ Semakin tinggi konsentrasi antibakteri yang dihasilkan maka semakin tinggi pula daya hambatnya yang ditunjukkan oleh kecilnya pertumbuhan koloni bakteri patogen. ${ }^{33}$

Setiap tanaman dapat mengandung beberapa bakteri endofit yang mampu menghasilkan senyawa biologi atau metabolit sekunder yang di duga sebagai akibat koevolusi atau transfer genetik dari tanaman inangnya kedalam bakteri endofit. $^{34}$

Identifikasi bakteri endofit dilakukan berdasarkan hasil morfologi koloni dan morfologi sel serta aktivitas biokimia. Identifikasi mengacu pada pada Bergey's Manual of Determinative
Bacteriology. Berdasarkan buku Bergey's Manual Of Determinative Bacteriology bakteri yang memiliki potensi sebagai antibakteri tersebut merupakan bakteri genus Pseudomonas dikarenakan memiliki karakterisitik morfologi sel dan morfologi sel yang sama serta aktivitas biokimia yang sama.

Pseudomonas dapat ditemukan di tanah, air, tumbuh tumbuhan dan manusia. Dari beberapa penelitian ditemukan adanya bakteri endofit Pseudomnas sp endofit dari tanaman yang memiliki efek baik yaitu senyawa metabolit Pseudomonas sp endofit dari jagung mampu menghambat Fusarium sp. ${ }^{35}$ kemudian 2 isolat bakteri endofit dari tanaman dahlia yaitu Pseudomonas stutzeri LBKURCC44 dan Pseudomonas cepacia LBKURCC47 yang menunjukkan aktivitas antibakteri terhadap Escherichia coli dan Staphylococcus aureus. ${ }^{36}$

Hasil Uji fitokimia yang telah dilakukan oleh Halim, menunjukan bahwa Pseudomonas sp. positif mengandung 
saponin dan terpenoid. ${ }^{37}$ Saponin

merupakan senyawa glikosilat yang

terdapat dalam sel tanaman sebagai

prekursor tidak aktif tetapi siap diubah

menjadi senyawa bioaktif antibiotik oleh

enzim apabila diserang oleh patogen. ${ }^{38}$

Mekanisme terpenoid sebagai antibakteri

adalah bereaksi dengan porin (protein

transmembran) pada membran luar dinding

sel bakteri, membentuk ikatan polimer

yang kuat sehingga mengakibatkan

rusaknya porin. ${ }^{39}$

\section{KESIMPULAN}

Berdasarkan hasil dan pembahasan

dari penelitian yang telah dilakukan, dapat

disimpulkan bahwa :Hasil identifikasi

menunjukan bahwa isolat 16 memiliki

kemiripan dengan genus Pseudomonas

dan Isolat 16 memiliki aktivitas zona

hambat yang paling tinggi dengan

membentuk zona hambat sebesar $6,5 \mathrm{~mm}$

serta Siprofloksasin yang digunakan

sensitif terhadap bakteri Escherichia coli dengan membentuk zona hambat sebesar

$39 \mathrm{~mm}$

\section{DAFTAR PUSTAKA}

1. Kasper DL, Hauser SL, Jameson JL, Fauci AS, Longo DL, Loscaizo J, et al. Harrison's Internal Medicine. 19th Edition. USA. McGraw - Hill; 2015.

2. Kementrian Kesehatan Republik Indonesia (Kemenkes RI) Profil data kesehatan Indonesia tahun 2015. Jakarta: Kementrian Kesehatan RI; 2016.

3. Profil Dinas Kesehatan Kota Pontianak. Kasus Diare, Seksi Pengendalian Penyakit, Dinas Kesehatan Kota Pontianak. Pontianak; 2015.

4. Farthing M, Lindberg G, Dite P, Khelif I, Lindo ES, Ramakrishna BS, et al. Acute diarrhea. World Gastroenterology Organisation Practice Guideline.2012[cited 2016 Des 23]. Available From : http://www.worldgastro enterology.org.

5. Brooks GF, Butel JS, Morse SA. Jawetz, Melnick \& Adelberg's Medical Microbiology. 27th ed. USA: The McGraw-Hill; 2016.

6. Qadri F, Svennerholm AM, Faruque AS, Sack RB. Enterotoxigenic Escherichia coli in developing countries: epidemiology, microbiology, clinical features, treatment, and prevention. Clin Microbiol Rev. 2005;18:46583.

7. Kitaoka M, Miyata ST, Unterweger D, Pukatzki S. Antibiotic resistance mechanisms of vibrio cholerae. J of Med Microbiol. 2011;60(4):297407.

8. Permenkes RI. Pedoman Umum Penggunaan Antibiotik, Kementrian Kesehatan RI. Jakarta; 2011.

9. Akbar M, Budiarti LY, Edyson. Perbandingan efektivitas antibakteri antara ekstrak metanol kulit batang kasturi dengan ampisilin terhadap Staphylococcus aureus in Vitro. Jurnal Berkala Kedokteran, 2016;12(1): 1-9.

10. Lusiana, Dhafir F, Masrianih. Pengaruh Pemberian Ekstrak Daun Pegagan (centella asiatica) terhadap Mortilitas Spermatozoa Mencit (Mus musculus) Galur Ddy. E-jipbiol, 2013;2:24-29.

11. Brinkhaus B, Lindner M, Schuppan D, Hahn EG. Chemical, pharmacological and clinical profile of the East Asian medical plant Centella asiatica. Phytomedicine. ErlangenNuremberg. 2000;7(5):427-488.

12. Dalimartha, S. Atlas Tumbuhan Obat Indonesia. Jilid 2. Jakarta: Trubus Agriwidya; 2008.(cited 2016 Des 23)Availablefrom; https://books.Google .co.id/books?id=vmrbQE4jfYcC\&printsec=fr 
ontcove \&hl=id\&source $=\mathrm{gbs}$ ge _summary_r\&cad=0\#v=onepage \&q\&f=false.

13. Sundaryono, A. Penggunaan batang tanaman betadin ( Jatropha multifida L.) untuk meningkatkan jumlah Trombosit pada Mus Musculus. Artikel asli Media Medika Indoesiana. 2011;45(2):1-5.

14. Brinkhaus B, Lindner M, Schuppan D, Hahn EG. Chemical, pharmacological and clinical profile of the East Asian medical plant Centella asiatica. Phytomedicine. ErlangenNuremberg. 2000;7(5):427-488.

15. Panthi,MP, Chaudhary,RP Antibacterial activity of some selected folklore medicinal plants from West Nepal. Scientific world. 2006;4(4):16-21.

16. Pratiwi BE. Isolasi dan skrining fitokimia Bakteri Endofit dari daun Rambutan (Nephelium lappaceum L.) Yang Berpotensi Sebagai Antibakteri [skripsi]. Jakarta. UIN; 2015.

17. Bhore SJ, Sathisha G. Screening of endophytic colonizing bacteria for cytokininlike compounds: crude cell-free broth of endophytic colonizing bacteria is unsuitable in cucumber cotyledon bioassay. World J. Agric. Sci. 2010;6(4):345-352.

18. Barbara JES, Christine JCB. 2006. What are Endophytes. In Microbial Root Endophytes (Eds: Thomas N. Sieber). Springer-Verlag, Berlin.

19. Altahi, AD. Plasmid profiles, antibiotic and heavy metal resistance incidence of endhophytic bacteria isplaterd from grapevine ( Vitis vinivera L. ), African J. of Biotech. 2009;8(21):5873-5882.

20. Vega FE, Ripoll M, Posada F, Buyer JS. Endophytic bacteria in Coffea Arabica L. J. Basic. Microbiol, 2005;45:371-380.

21. Castillo U, et al. Kakadumycins, novel antibiotics from Streptomyces sp.NRRL 30566, an endophyte of Grevillea pteridifolia. FEMS Microbiology Letters. 2003;224:180190.

22. Guan SH, Sattler I, Lin WH, Guo DA, Grabley S. p-Aminoacetophenonic acids produced by a mangroveendophyte: Streptomyces griseus subspecies. J Nat Prod. 2005;68:1198-200.

23. Ryan RP, Germaine K, Franks A, Ryan DJ, Dowling DN. Bacterial endophytes: recent developments and applications Mini Review. FEMS Microbiol Lett. 2008;(278):1-9.

24. Nursulistyarini F. Isolasi dan Identifikasi Bakteri Endofit Penghasil Antibakteri dari daun Tanaman Binahong (Anredera ccordifolia (Ten.) steenis) [Skripsi]. Yogyakarta: Universitas Negeri Sunan Kalijaga; 2014.
25. Besung, INK. Pegagan (Centella aisatica) sebagai alternative Pencegahan Infeksi pada ternak. Buletin veteriner udayana. 2009;6167:2.

26. Toy TSS, Lampus BS, Hutagalung BSP. Uji Daya Hambat Ekstrak Rumput Laut Gracilaria Sp Terhadap Pertumbuhan Bakteri Staphylococcus Aureus. E-GigI. 2015;3(1):17.

27. Hallmannn J, Quadt-Hallmannn A, Mahaffee WF, Kloepper JW.. Bacterial endophytes in agricultural crops. Can J Microbiol. 1997; 43:895-914

28. Bacon CW, Hinton DM.. Bacterial endophytes: the endophytic niche, its occupants, and its utility. Di dalam: Gnanamanickam SS, editor, Plant- Associated Bacteria. Netherland : Springer. 2006

29. Sulistiyani TR. Keragaman bakteri endofit tanaman kunyit putih (Curcuma zedoaria) dan toksisitasnya terhadap embrio ikan zebra. [Tesis]. Bogor: Institut Pertanian Bogor. 2014

30. Kumala S, Siswanto EB. Isolation and screening of endophytic microbes from Morinda citrifolia and their ubility to produce antimicrobial subtances. Microbiology Indonesia. 2007;1: 145-148

31. Sari WE. Aktivitas antihipertensi aktinomiset endofit asal tanaman pegagan dan belimbing wuluh [skripsi]. Bogor (ID): Fakultas Matematika dan Ilmu Pengetahuan Alam, Institut Pertanian Bogor, 2011.

32. Radji, M. Peranan bioteknologi dan mikroba endofit dalam pengembangan obat herbal. Pharmaceutical Sciences and Research, 2012; 2(3):113-126

33. Strobel, GA. Microbial gifts from rain forests. Canadian Journal of Plant Pathology, 2002; 24(1):4-20.

34. Sunariasih, Linda NP, Suada IK, Suniti NW. Identifikasi jamur endofit dari biji padi dan uji daya hambatnya terhadap Pyricularia oryzae Cav. Denpasar. E-jurnal ageoteknologi tropika 2014;3(2).

35. Tan RX, Zou WX.. Endophtyes: a rich source of functional metabolites. Nat Prod Rep; 2001;18: 4483459

36. Hanif, Andini, Bonny P, Wahyu S, Munif A. Seleksi Bakteri Endofit Penghasil Senyawa Metabolit untuk Pengendalian Cendawan Patogen Terbawa Benih Jagung. Jurnal Fitopatologi Indonesia. 2017;12(5)149

37. Elita A, Saryono S, Jose C. Penentuan waktu optimum produksi antimikroba dan uji fitokimia ekstrak kasar fermentasi bakteri endofit Pseudomonas sp. dari umbi tanaman dahlia (Dahlia variabilis). Jurnal Indonesian Chemia Acta, 2013;3(2):56-62.

38. Halim, Jasril, Saryono. Optimalisasi produksi senyawa metabolit sekunder dari 
pseudomonas sp. Endofit tanaman dahlia (Dahlia variabilis). Jurnal indonesian chemia acta, 2014, 5.1: 8-14.

39. Turk FM. Saponins versus plant fungal pathogens, Journal of Cell and Molecular Biology. 2006; 5:13-17. 